\title{
小児急性化膿性中耳炎の細菌学的検討
}

\author{
内藤 雅夫・鈴木 昭男 - 桑内 隆郎・松永 仁毅 \\ 森茂樹・西村 忠郎・岩田 重信
}

\section{A Bacteriological Study of Acute Purulent Otitis Media in Ghildren}

\section{Masao Naito, Akio Suzuki, Takao Kuwauchi, Hitoki Matsunaga, Shigeki Mori, Tadao Nishimura and Shigenobu Iwata}

(Fujita-Gakuen Universitv)

A bacteriological study was carried out on middle ear discharge in 157 cases of fresh acute purulent otitis media in children. The middle ear discharge was collected with sterile cotton swabs after paracentesis and cultured in chocolate agar medium, sheep blood agar medium and DHL medium.

The results were as follows.

1) The most frequent organism found independently was Haemophilus influenzae $(32 \%$ of 119 strains) and next in frequency was Streptococcus pneumoniae $(29 \%)$ followed by Staphylococcus epidermidis $(16 \%)$ and Staphylococcus aureus $(8 \%)$. Streptococcus pyogenes was found in $3 \%$.

2) The number of mixed isolates were 38 and Staphylococcus epidermidis was found in $74 \%$ of these cases.

3) Haemophilus influenzae and Streptococcus pneumoniae were a very important causative pathogen of acute purulent otitis media.

Ampicillin (ABPC) is the antibiotic of choice.

\section{は じめに}

小㫛の急性化膿性中耳炎は頻度の高い重要な疾患であり，一般に細菌によってひき起てされるこ とが多く起炎菌の検討は治療に直結した大切な問題である. 細菌感染症の起炎菌の検討には未治療 の新鮮例を対象とすることが重要であるけれども近年の医療施設の充実および分業化により一般的 大学病院においてそのような症例に遭遇する機会は非常に少なくなり, そのため正確な起炎菌の推 定が困難となっている．乙の点において我々の施設は大学病院ではあるけれどあ地域のプライマリ 一ケアホスピタルの性格む有し，新鮮症例を数多く取り扱かい“急性中耳炎の起炎菌”に取り組む のに好都合である，そこで最近の検出菌の傾向を過去の報告例と比較しながら検討を加え，さらに 実際の治療時の抗生剤感受性についても検討したので報告する. 


\section{対象および方法}

昭和 55 年 1 月より昭和 56 年 12 月までに当病院 耳鼻咽喉科を受診した15才以下の未治療急性化 膿性中耳炎 157 例である．外耳道をヒビテング リコネートで十分清拭ののち鼓膜切開を施行 し, 流出した中耳則留液を滅菌綿棒で採取, 直 ちに血液寒天培地に塗抹, 速や加当院中央細 菌検査室へ移送し分離同定および薬剤感受性試 験を実施した。

結

1 ) 単独検出菌

単独に検出された 119 株の種類と年令分布 は表 2 に示した。検出菌はインフルエンザ菌 Haemophilus influenzae 38株 32\%, 肺炎球菌 Streptococcus pneumoniae 34 株 $29 \%$ とこの 2 種で $61 \%$ 占めている．次いで表皮ブドウ球菌 Staphylococcus epidermidis（以下表皮ブ菌） 20株 $16 \%$, 黄色ブドウ球菌 Staphylococcus aureus（以下黄色ブ菌）10株 $8 \%$, 溶血性連鎖 球菌 Streptococcus pyogenes (以下溶連菌) 3 株 $3 \%$ あ゙あった。なおその他としては枯草菌, パラインフルエンザ菌, ナイセリア, 乳酸桿菌 が少数例認められた。年令との関係ではインフ ルエンザ菌, 肺炎球菌は各年令から広く検出さ

\section{表 I}

使用培地

1) ヒツジ血液加寒天培地

2) チョコレート寒天培地

3) D H L培地

感受性ディスク

ショーワ 1 濃度ディスク

果

れているが，黄色ブ菌は 0 才，1才に $80 \%$ が検 出されている.

\section{2 ) 混合検出菌（表 3 ）}

2 種以上が同時に検出されたものは38例あり インフルエンザ菌と表皮ブ菌, 肺炎球菌と表皮 ブ菌との組み合わせがそれぞれ 8 例ずつ，また 黄色ブ菌と表皮ブ菌の組み合わせが 6 例など表 皮ブ菌が同時に検出された例が38例中 28 例 $74 \%$ と非常に高率となり，表皮ブ菌の外耳道あるい は鼓膜表面での混入が推定される.

3 ) 季節之検出菌（表 4 ）

インフルエンザ菌は春と冬に多く検出され肺 炎球菌は春，秋，冬とほぼ同程度であるが表皮 ブ菌は夏に半数以上が検出され, 高温多湿の気

表 2 単独検出菌

\begin{tabular}{|c|c|c|c|c|c|c|c|c|c|}
\hline 菌 種 年 & 0 & 1 & 2 & 3 & 4 & 5 & 6 & 7 & 計 \\
\hline H. influenzae & 2 & 5 & 7 & 6 & 4 & 8 & 3 & 3 & 38 \\
\hline St. pneumoniae & 3 & 2 & 5 & 7 & 3 & 7 & 4 & 3 & 34 \\
\hline S. aureus & 3 & 5 & & & & & 1 & 1 & 10 \\
\hline S. epidermidis & 2 & 4 & & 1 & 1 & 7 & 2 & 3 & 20 \\
\hline St. pyogenes & & 1 & & & & 2 & & & 3 \\
\hline H. parainf. & 1 & 1 & & & & & 1 & & 3 \\
\hline Others & 1 & 1 & & & 3 & 4 & 1 & 1 & 11 \\
\hline 計 & 12 & 19 & 12 & 14 & 11 & 28 & 12 & 11 & 119 \\
\hline
\end{tabular}


表 3 混合検出菌

$$
\begin{aligned}
& \text { H. influenzae } \\
& + \text { S. epidermidis } 8 \\
& +\mathrm{S} \text { aureus } 2 \\
& + \text { S. epidermidis }+ \text { S. aureus } 2 \\
& +\mathrm{S} \text {. epidermidis }+\alpha \text {-streptococcus } 1 \\
& + \text { S. epidermidis }+ \text { Neisseria } 1 \\
& + \text { Neisseria } 1 \\
& + \text { St. hemolyticus }+ \text { S. aureus } 1 \\
& + \text { St. pneumoniae }
\end{aligned}
$$

St. pneumoniae

+ S. epidermidis 8

+ S. epidermidis + S. aureus 2

$+\mathrm{S}$. aureus $+\mathrm{H}$. influenzae 1

+ S. aureus 1

S. aureus

+ S. epidermidis

others

3

候がこの菌の繁殖の助けになっているものと思 われる.

\section{4 ）薬剤感受性（表 5 ）}

内服可能な 4 種の抗生剂 ampicillin(ABPC), cephalexin (CEX), minocycline (MINO), erythromycin (EM) のディスク法による感 受性判定の結果である.インフルエンザ菌は $\mathrm{ABPC}$ 耐性株が55年 $17 \%, 56$ 年 $5 \%$ 認められ るがこれらの株が $\beta$ ラクタマーゼ産生株か否か は不明である。一方 C EXは両年とも $83 \%$ の感 性率であるが ABPC のそれとあまり差がな く,ディスク法の読みのむづかしさとも考えら れる。肺炎球菌は ABPC, CEX とも全例 $(H)$ 以上の感受性を持っているが EMは55年 $11 \%$,

\begin{tabular}{|c|c|c|c|c|c|}
\hline & 春 & 夏 & 秋 & 冬 & 計 \\
\hline H. influenzae & $26^{\text {株 }}$ & 11 & 5 & 14 & 56 \\
\hline St. pneumoniae & 17 & 9 & 10 & 11 & 47 \\
\hline S. aureus & 8 & 10 & 1 & 6 & 25 \\
\hline S. epidermidis & 13 & 26 & 10 & 2 & 51 \\
\hline St. pyogenes & 1 & 2 & 1 & 1 & 5 \\
\hline others & 7 & 4 & 4 & 4 & 19 \\
\hline 計 & 72 & 62 & 31 & 38 & 203 \\
\hline $\begin{array}{ll}\text { 春 } & 3 . \\
\text { 夏 } & 6\end{array}$ & $\begin{array}{l}\cdot 5 \\
\cdot 8\end{array}$ & & $\begin{array}{c}9 \\
12\end{array}$ & $\begin{array}{l}10 \cdot 1 \\
1 \cdot\end{array}$ & \\
\hline
\end{tabular}
56 年 $20 \%$ の耐性株が認められる。 また黄色ブ菌 は55年の $\mathrm{ABPC}$ の感性率が $64 \%$ と比較的良好

\section{考}

急性中耳炎の起炎菌の年代的変化を検討する 時必要な条件としては対象症例, 検体の採取方 法および使用培地を出来るだけ同一なものを選 ぶということである.すなわち新鮮例に対して
表 4 季節と検出菌

表 5 薬剤感受性

\begin{tabular}{ccccc}
\hline & ABPC & CEX & MINO & EM \\
H. influenzae & & & & \\
55年 (36株) & $83 \%$ & 83 & 97 & 83 \\
56年 (19株) & 95 & 83 & 100 & 84 \\
St. pneumoniae & & & & \\
55年 (25株) & 100 & 100 & 100 & 89 \\
56年 (21株) & 100 & 100 & 95 & 80 \\
S. aureus & & & & \\
55 年 (12株) & 64 & 86 & 100 & 50 \\
56 年 (13株) & 23 & 77 & 100 & 50 \\
S. epidermidis & & & & \\
55年 (26株) & 82 & 92 & 100 & 62 \\
56 年 (7 株) & 14 & 86 & 100 & 29
\end{tabular}

Disk 法にて(H)以上を感受性ありと判定.

であったが56年には $23 \%$ と急激に耐性化が進ん でいる．全体的に MINO の感受性の良いのが 目につくがこのととに関しては考察で検討を加 えたい.

\section{察}

穿刺あるいは切開により直接鼓室から貯留液を 採取し，推定される菌の発育に最も適した培 地，たとえばインフルエンザ菌に対するチョコ レート寒天培地を使用しているかどうかなどの 
配慮が必要になってくる，ての様な条件を満た した過去の報告をさがしてみると1934年伊藤"

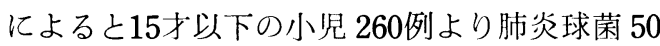
$\%$, 溶連菌 $31 \%$, インフルエンザ菌 $17 \%$ とての 3 種で $98 \%$ を占め, 黄色ブ菌の検出率はわずか に1.5\%にすぎなかった。また 1941 年更科2)は 192例の小児から肺炎球菌 $44 \%$, 溶連菌 $25 \%$, インフルエンザ菌 $13 \%$, ブドウ球菌 $9 \%$ と比較 的同傾向の報告をおてなっている．1950年以後 には福田 ${ }^{3)}$ ，三宅 ${ }^{4)}$ ，浅野5)らの報告屯見られる が発症からかなりの時間を経過したあのおよび 耳漏症例が多く，さらには使用培地の選択等か ら同一には論じられないと思われる．1979年に は杉田 ${ }^{6)}$ が鼓膜切開を施行した92例より肺炎球 菌63\%, インフルエンザ菌 $24 \%$, 溶連菌 $6 \%$, 黄色ブ菌 $7 \%$ と報告し, 1980年になると藤田 は新鮮例 100例より肺炎球菌 $28 \%$ ，インフルエ ンザ菌26\%，黄色ブ菌19\%，溶連菌 $6 \%$ 之報告

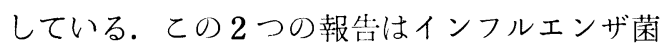

検出率の増加, 溶連菌検出率の減少などほぼ我 々の成績と同傾向である.1950年以前と自験例 も含めた最近の報告との大きな相違点は溶連菌 とインフルエンザ菌の検出頻度である。すなわ 与伊藤, 更科は溶連菌の検出率をそれぞれ $31 \%$, 25\%としているが最近ではすべて $10 \%$ 以下であ る.乙の変化の大きな原因としてはサルファ剤 および抗生剂の普及にあると思われる。また同 定法の進歩により以前は溶連菌之考えられてい たものが現在では肺炎球菌之同定される場合も 少なからず存在すると推定される。一方インフ ルエンザ菌の増加に関しては培養技術の進歩と ともにこの菌に感受性の弱いC EX 使用量の急 激な増加屯原因となっていると思われる. こて で1950年以後多くの報告で高率に検出されてい る黄色ブ菌について若干述べてみたい，黄色ブ 菌の検出率の高い報告は発症から来院までの時 間が長かったり，耳漏を綿棒で採取し検体とし ている場合が多く，杉田 ${ }^{8)}$ は検体採取方法によ

\section{表 6 肺炎球菌のM I C}

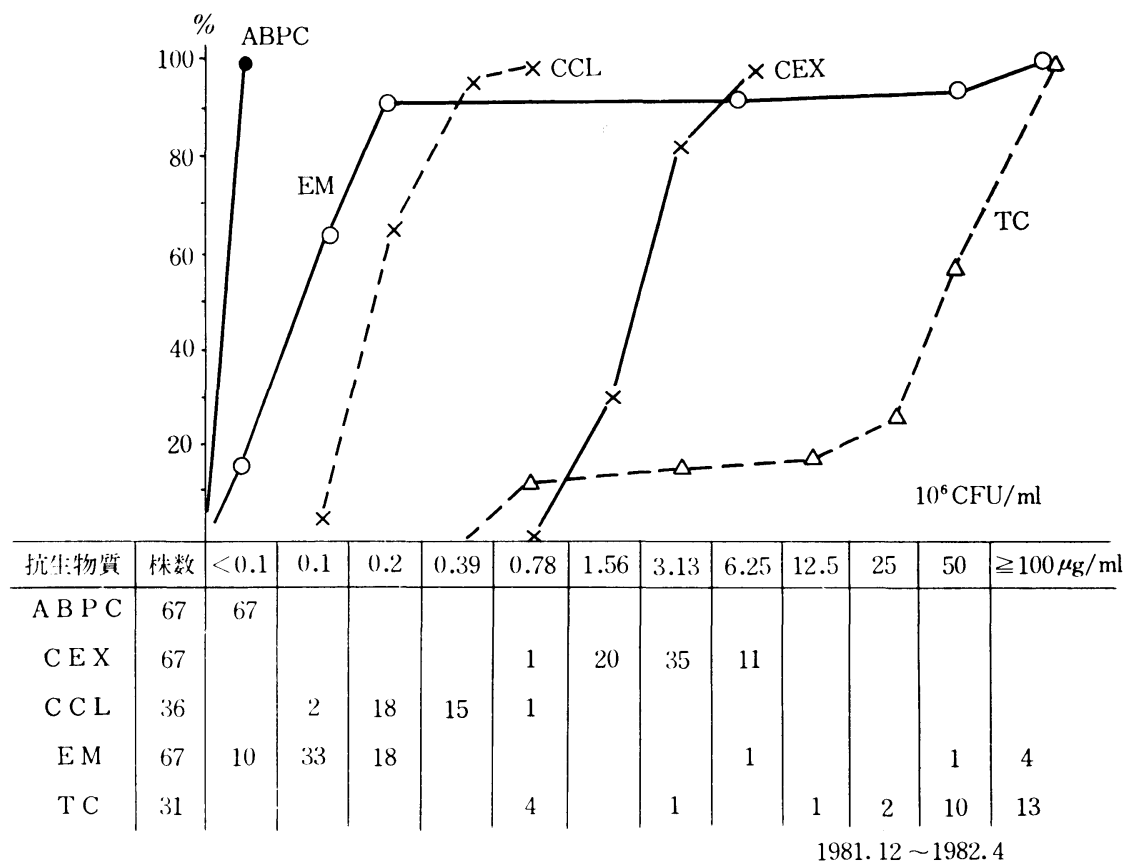

（東京総合臨床検査センター） 
る菌検出頻度の比較を行ない統計学的にも耳漏 症例からは黄色ブ菌が有意に検出されるとして いる.さらに上咽頭の菌検にても黄色ブ菌の検 出される割合は非常に少なく ${ }^{188}$, 急性中耳炎の 発症が主として経耳管感染であるととから黄色 ブ菌の起炎性はかなり低いと考えたい。また自 験例では表皮ブ菌が $17 \%$ 検出されているが外耳 道には表皮ブ菌が高率に存在する ${ }^{199}$ ため消毒 を十分におてなったとして屯辪膜切開後流出し た眝留液を採取しているかぎりある程度の混入 はさけがたく，起炎菌の検㣙からは除外するの

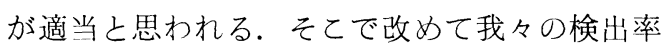
を出してみるとインフルエンザ菌38\%, 肺炎球 菌34\%となりこの 2 種の占める割合は $72 \%$ と高 率になる，以上より小児急性化膿性中耳炎の起 炎菌としては肺炎球菌, インフルエンザ菌が最 屯重要と考える.

つぎに薬剤感受性検査とそれを参考にして抗 生剂の選択について検沽する，我々の施設では
M I C (最小発育阻止濃度) の測定を行ってい ないので東京総合臨床検査センターにて1981年 12月～82年 4 月までの小児急性化膿性中耳炎症 例より分離された菌株のデータを参考にしてデ ィスク法との比較を行ってみる，肺炎球菌はデ ィスク法では ABPC, CEX ともに全株(H)以 上であったが, M I C (表6) では ABPCは 全株 $0.1 \mu \mathrm{g} / \mathrm{ml}$ 以下であり C EXは $0.78 \sim 6.25$ $\mu \mathrm{g} / \mathrm{ml}$ に分布しピークは $3.13 \mu \mathrm{g} / \mathrm{ml}$ である. 同 じ (H) (H)で屯実際の感受性としてはC EXは ABPC にかなり少っている.しかし最近発壳さ れたセファロスポリン系内服剤である Cefaclor (CCL) は $0.1 \sim 0.78 \mu \mathrm{g} / \mathrm{ml}$ にM I Cをも ち C EXよりは効果が期待出来ると思われる. 一方55年 $100 \%, 56$ 年 $97 \%$ 之高感受性をしめし た MINO は T C と比較すると 2 倍から 4 倍程 度感受性がよいが, T Cの M I C は 70\%が 50 $\mu \mathrm{g} / \mathrm{ml}$ 以上でありディスク法の結果をうのみに するのはかなり危険である. インフルエンザ菌

表 7 インフルエンザ菌のM I C

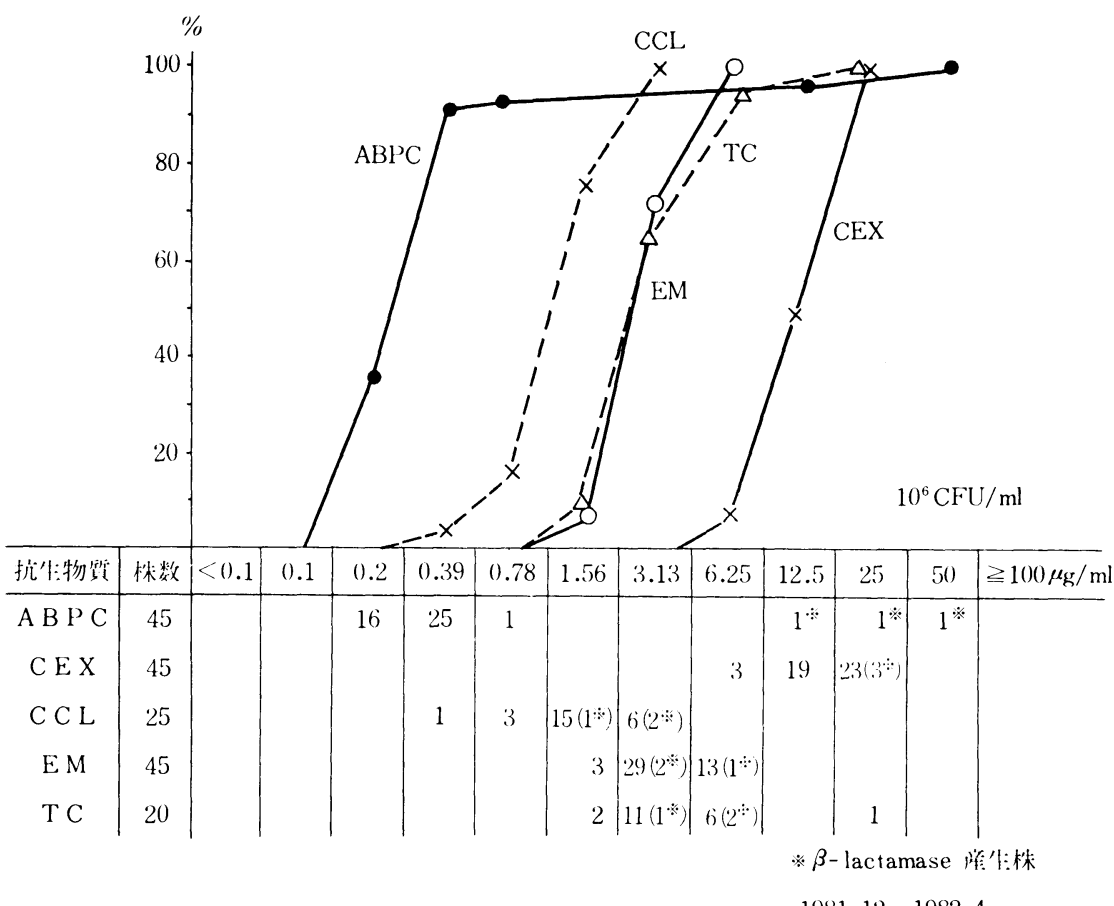

1981. $12 \sim 1982.4$

（東京総合臨床検査センター） 
（表 7 ）についても ABPC の感性率 55 年 83

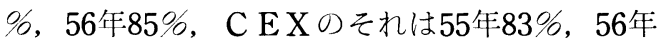
83\%と両者にはあまり着がみられないがM I C は 45 株中 42 株が $0.2 \sim 0.78 \mu \mathrm{g} / \mathrm{ml}$ であり, C E $\mathrm{X}$ は $12.5 \sim 25 \mu \mathrm{g} / \mathrm{ml}$ に 42 株が分布し両者には 大きな养が認められる.インフルエンザ菌に対 しては常用量の内服では C EXはほとんど効果 が期待出来ない. しかし ABPC でも肺炎球菌 に対する感受性と比較すると必ずしもよくはな く, この菌が検出され治療効果の薄い時には増 量投与, あるいは注射の併用も必要之思われ る. また約 $10 \%$ の $\beta$ ラクタマーゼ産生株も検出 されているので注意が必要である.

我々の施設では C EX および MINO の感受 性が全般的によく出る傾向にあり, ディスク法 では同じ $(H)(H+$ )でも各䀤剈間には抗菌力に差 がある場合も多く治療にあたっては目的菌に対
するM I C の分布む念頭におく必要を痛感す る. 日本における経口抗生㓣使用量は CEX, $\mathrm{ABPC}$ が断然多くとりわけC EXの使用量が 大であるが急性中耳炎の治療においてはその推 定起炎菌からCEX使用の意義はほとんどな く, ABPC 系が第1に選ばれるべきであるこ とを強調したい。

しかし実際には菌検結果, 治療効果をみなが ら使用抗生剂の変更む必要であり, それと同時 に鼻咽腔の所見を適切につかみ，対処していく ことが重要である．なお毎年多くの新しい抗生 物質が開発されてきているがほとんど注射剤で あり, 本疾患の治療はやはり経口投与が主体に なるのでインフルエンザ菌, 肺炎球菌特にイン フルエンザ菌にすぐれた抗菌力をもつ経口剤の 開発が強く望まれる.

\section{ま と め}

昭和 55 年, 56 年の 2 年間に経験した 15 才以下の未治療急性化膿性中耳炎 157 例を対象に検出菌の 頻度, その意義および薬剤感受性を検討した。

1 ）単独検出菌は 117 株ありその内訳は，インフルエンザ菌 $32 \%$, 肺炎球菌 $29 \%$, 表皮ブ菌 $16 \%$, 黄色ブ菌 $8 \%$, 溶連菌 $3 \%$ などであった.

2 ） 2 種以上同時に検出された例は 38 例ありその $74 \%$ 表皮ブ菌が検出された.

3 ）インフルエンザ菌, 肺炎球菌はほぼ全年介に検出された.

4 ）小児急性化膿性中耳炎の起炎菌はインフルエンザ菌, 肺炎球菌が主体である.

5 ) ディスク法での楽剤感受性は肺炎球菌, インフルェンザ菌ともに ABPC, CEX に高感受性 であったが, 最小発育阻止濃度を加味すると ABPC がまさっている.

6 ）小児急性化膿性中耳炎に対して第一選択となる経口薬剤は ABPC 系であるが, インフルエ ンザ菌に対しては増量投与あるいは注射の併用も必要である。

本論文の要旨は第11回日本耳鼻咽喉科感染症研究会および第27回東海地方部会連合会において口演した.

\section{文}

1) 伊藤光隆 : 急性化膿性中耳炎の細菌学的研究. 慶 応医学 $16: 617 \sim 708,1934$.

2 ) 更科兼三: 急性中耳炎の細菌学的研究. 衛生学伝 染病学雑誌 $37: 107 \sim 210,1941$.

3 ）福田典男：急性中耳炎の細菌叢特にペニシリン而 性に就いて. 熊本医学誌 $30: 39 \sim 43,1956$.

4 ) 三宅弘：最近の急性中耳炎起炎菌と Erythro-

\section{献}

mycin estolate 療法の臨床. 耳喉 38:1109 1114, 1966.

5 ) 浅野 尚: 耳漏中の細菌とその薬剤感受性. 耳喉 $44: 905 \sim 910,1972$.

6）杉田麟也：急性化膿性中耳炎の起炎菌. 日耳鼻 $82: 568 \sim 573,1979$.

7 ) 藤田晃三：小児急性中耳炎からの分離菌と薬剤感 
受性. 日児誌 $84 ： 231 \sim 235,1980$.

8 ) 杉田䗲也：急性化膿性中耳炎の薬剤選択. 日耳鼻 $82: 1381 \sim 1387,1979$.

9) 杉田麟也：慢性中耳炎の細菌学的研究. 日耳鼻 $80: 907 \sim 919,1977$.
別刷請求先：内藤雅夫

厂470-11 豊明市沓掛町田楽ケ窪 $1-98$ 名古屋保健衛生大学医学部耳鼻咽喉科学 